\title{
Deep-Water Flow in the Mariana and Caroline Basins*
}

\author{
Gerold Siedler, ${ }^{+}$Jürgen Holfort, ${ }^{\#}$ Walter Zenk, Thomas J. Müller, and Tiberiu Csernok \\ Institut für Meereskunde, Kiel, Germany
}

(Manuscript received 27 February 2003, in final form 13 July 2003)

\begin{abstract}
Two major water masses dominate the deep layers in the Mariana and Caroline Basins: the Lower Circumpolar Water (LCPW), arriving from the Southern Ocean along the slopes north of the Marshall Islands, and the North Pacific Deep Water (NPDW) reaching the region from the northeastern Pacific Ocean. Hydrographic and moored observations and multibeam echosounding were performed in the East Mariana and the East Caroline Basins to detail watermass distributions and flow paths in the area. The LCPW enters the East Mariana Basin from the east. At about $13^{\circ} \mathrm{N}$, however, in the southern part of the basin, a part of this water mass arrives in a southward western boundary flow along the Izu-Ogasawara-Mariana Ridge. Both hydrographic observations and moored current measurements lead to the conclusion that this water not only continues westward to the West Mariana Basin as suggested before, but also provides bottom water to the East Caroline Basin. The critical throughflow regions were identified by multibeam echosounding at the Yap Mariana Junction between the East and West Mariana Basins and at the Caroline Ridge between the East Mariana and East Caroline Basins. The throughflow is steady between the East and West Mariana Basins, whereas more variability is found at the Caroline Ridge. At both locations, throughflow fluctuations are correlated with watermass property variations suggesting layerthickness changes. The total transport to the two neighboring basins is only about 1 Sverdrup $\left(1 \mathrm{~Sv} \equiv 10^{6} \mathrm{~m}^{3}\right.$ $\mathrm{s}^{-1}$ ) but has considerable impact on the watermass structure in these basins. Estimates are given for the diapycnal mixing that is required to balance the inflow into the East Caroline Basin. Farther above in the water column, the high-silica tongue of NPDW extends from the east to the far southwestern corner of the East Mariana Basin, with transports being mostly southward across the basin.
\end{abstract}

\section{Introduction}

The relatively cold and saline deep waters in the equatorial western Pacific Ocean are essential components of the global thermohaline circulation. The basic physics of this large-scale circulation was first presented by Stommel (1958) and Stommel and Arons (1960a,b). In their simplified model, deep western boundary currents are generated, driven by the source-sink distributions of the global ocean and with uniform upwelling over a flat bottom. However, variable upwelling and bathymetric features will also play an important role in determining the deep circulation.

Observational evidence for deep western boundary currents in the Pacific Ocean was already given by Wüst $(1929,1930,1937)$ and Wyrtki (1961). Reid and Lynn (1971) traced cold and saline waters from the Norwegian-Greenland Sea through the Atlantic Ocean and the

\footnotetext{
* International Pacific Research Center Publication Number 219.

+ Additional affiliation: International Pacific Research Center, University of Hawaii at Manoa, Honolulu, Hawaii.

\# Current affiliation: Institut für Meereskunde, Hamburg, Germany.
}

Corresponding author address: Gerold Siedler, Institut für Meereskunde, Düsternbrooker Weg 20, 24105 Kiel, Germany.

E-mail: gsiedler@ifm.uni-kiel.de circumpolar current region to the Pacific. Indicators for bottom-water flow patterns in the western Pacific were given by Mantyla (1975) and Mantyla and Reid (1983), and the structure of water masses in the deep boundary currents in the southwestern Pacific and the related mixing effects were studied by Warren (1973) and Sokolov and Rintoul (2000).

Reid (1997) showed that the deep water is influenced by the overlying Antarctic Intermediate Water and the North Pacific Deep Water (NPDW). Relatively high values of oxygen decreasing to the north and low values of silica increasing to the north at this level in the western Pacific indicate the influence of the resulting Lower Circumpolar Water (LCPW) (Johnson and Toole 1993). Global patterns and transport rates of the thermohaline circulation on the basis of pre-WOCE (World Ocean Circulation Experiment) data were provided by Schmitz (1995, 1996a,b).

The present study has its focus on the deep-water flow in the equatorial western Pacific. The main deep-water masses in the region north of New Guinea have different histories and pathways. The LCPW moves past New Zealand, then northward to the east of the Tonga-Kermadec Ridge (Whitworth et al. 1999), and then through the Samoan Passage (Taft et al. 1991; Reid and Lonsdale 1974; Johnson et al. 1994; Roemmich et al. 1996; Rud- 


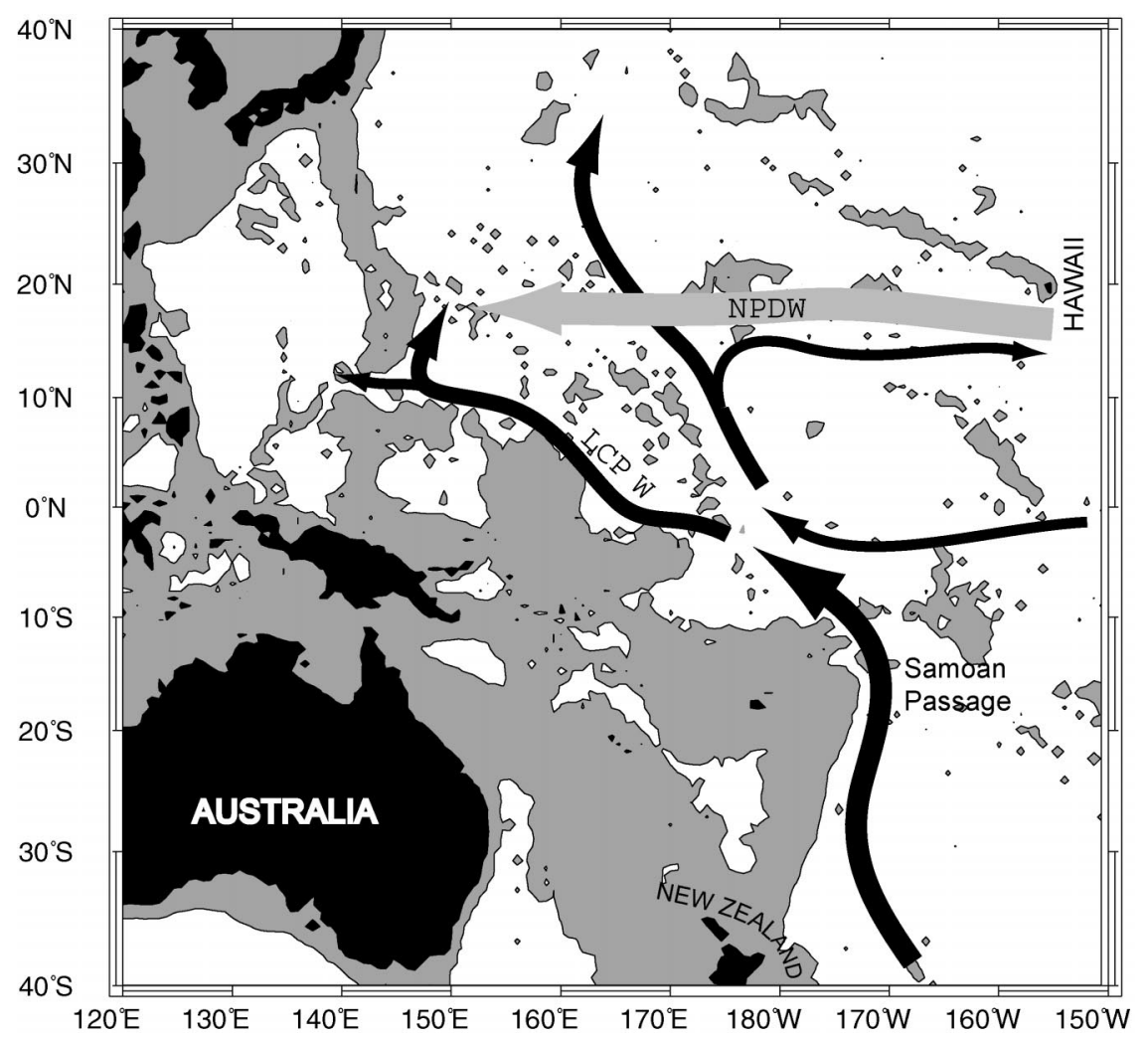

FIG. 1. Approximate flow paths of the LCPW and the NPDW in the western Pacific Ocean [after Johnson and Toole (1993) and Wijffels et al. (1996)].

nick 1997; Freeland 2001). Quantitative results from various WOCE measurements were used by Hogg (2001) to obtain a set of LCPW deep western boundary transport estimates in the western Pacific, with transports decreasing from about $16 \mathrm{~Sv}\left(1\right.$ Sverdrup $\equiv 10^{6}$ $\left.\mathrm{m}^{3} \mathrm{~s}^{-1}\right)$ at South Pacific subtropical latitudes to about 5-9 Sv at North Pacific subtropical latitudes.

The synthesis of hydrographic results (Johnson and Toole 1993) shows the LCPW flowing northward east of New Zealand and through the Samoan Passage (Fig. $1)$. The deeper and colder components continue northward in the Central Pacific Basin, mostly as a deep western boundary current near the Marshall Islands (Kawabe and Taira 1998), contributing to a large-scale North Pacific anticyclone. The LCPW at somewhat shallower levels flows to the northwest, crosses the equator, and moves through the East Mariana Basin, finally branching into a westward limb toward the West Mariana Basin (Parece Vela Basin) and a northward limb toward the Northwest Pacific Basin.

The NPDW reaches the region from the northeastern Pacific (Wijffels et al. 1996) with westward propagation south of the Hawaiian Islands (Fig. 1). It is being formed through mixing of water generated in the North Pacific and particularly with the imprint of a strong silica signal from bottom sources (Talley and Joyce 1992).

The distribution of deep-water masses in the region south and north of the equator between New Guinea and Guam is largely controlled by bottom topography, in particular by the structure of the West and East Mariana Basins and the West and East Caroline Basins with their separating ridges (Fig. 2). The pattern of deepwater masses in the region was studied by Kawabe (1993). He showed the oxygen-rich near-bottom water of South Pacific origin in the East Mariana Basin. Its high-oxygen signal can be followed on a northward track in that basin.

At somewhat shallower levels, deep water is able to cross the ridge from the East Mariana Basin to the West Mariana and Philippine Basins at the Yap Mariana Junction (YMJ), which lies to the southwest of Guam and at the southern end of the Izu-Ogasawara-Mariana Ridge (IOMR). The bottom property distributions of Mantyla and Reid (1983) and the distributions of properties above $3000 \mathrm{~m}$ of Kaneko and Teramoto (1985) already suggested such a flow. Uehara and Taira (1990) presented watermass property distributions from two sections at $12^{\circ}$ and $13^{\circ} \mathrm{N}$ indicating the throughflow of the upper part of the deep water to the Philippine Basin. Uehara et al. (1993) showed the deep-water-mass properties to be variable in the West Mariana Basin and homogeneous in the Philippine Basin, indicating older water in the latter basin. Kawabe (1993) identified the isopycnal $\sigma_{3}$ (subscript 3 for 3000-dbar reference level; 


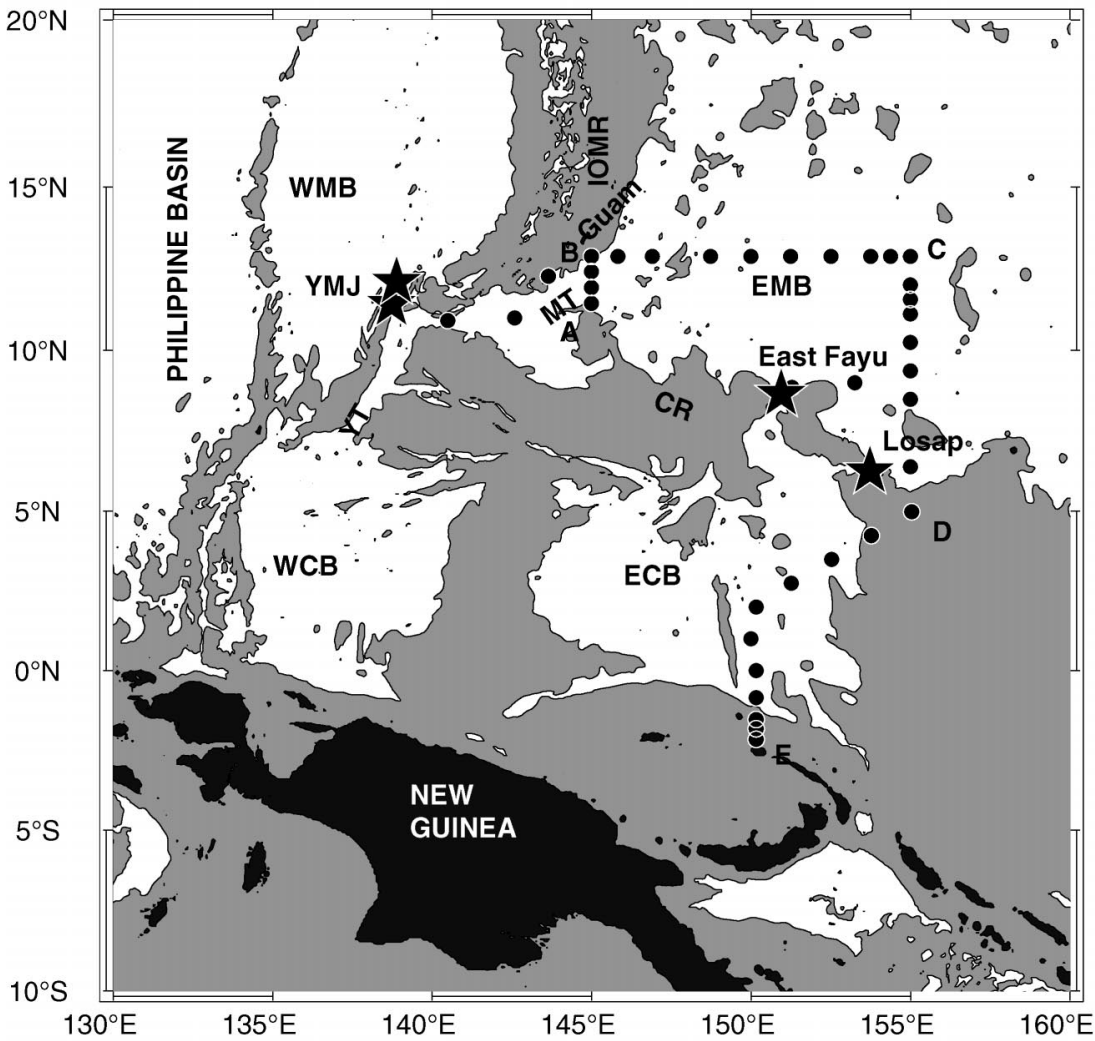

FIG. 2. The basin and ridge structure in the Mariana/Caroline region: WMB $=$ West Mariana Basin, $\mathrm{EMB}=$ East Mariana Basin, $\mathrm{WCB}=$ West Caroline Basin, $\mathrm{ECB}=$ East Caroline Basin, YMJ = Yap-Mariana Junction, IOMR = Izu-Ogasawara-Mariana Ridge, MT = Mariana Trench, and $\mathrm{CR}=$ Caroline Ridge. Gray areas indicate depths between 0 and $4000 \mathrm{~m}$. Section corner and end points are labeled A-B-C-D-E. Hydrographic stations are indicated by dots, and mooring positions are shown by stars.

$\sigma$ values henceforth given without units) characterizing the boundaries between throughflow and the nonthroughflow water in a section at $13^{\circ} \mathrm{N}$. According to this study, deep water at $\sigma_{3}=41.48$ crosses over to the West Mariana and Philippine Basins, water at $\sigma_{3}=$ 41.60 reaches the West Mariana Basin but cannot pass the ridge to the Philippine Basin, and the denser water at deeper levels is confined to the East Mariana Basin.

Reid's (1997) maps show patterns with westward propagation of deep water in the East Mariana Basin and northward flow along the IOMR at the western boundary, and a cross-over flow from the East Mariana to the West Marina Basin at 4000 dbar. In their study of tracer distributions during the Tropical Pacific Experiment (TROPAC; see below) Klatt and Holfort (2000) concluded that bottom water in the East Mariana Basin can be as young as 50-70 yr. Hydrographic data indicated the transition of deep water into the various basins, but the exact locations and depths of critical sills had not been identified. The West Caroline Basin is not a specific subject of the present study, but we refer to the description of water masses in that basin by Kaneko et al. (1998).
Kashino et al. (1996) and Wijffels et al. (1996, 1998) described the full-depth meridional watermass structure in the eastern Caroline and Mariana Basins on the basis of selected WOCE datasets. Further quasi-synoptic data on deep-water-mass distributions in the Mariana and Caroline Basins and on currents in passages were obtained during the TROPAC experiment (see below). These data are used here to provide new information on the deep-water-mass structure in the western equatorial Pacific, to identify critical sills between the Mariana and Caroline Basins, to detail corresponding layers of throughflow water, to estimate approximate transports and mixing rates, and to look at water property changes in relation to throughflow variability.

\section{Datasets}

The data used for the following analysis were primarily obtained during the TROPAC cruise of the German research vessel Sonne in October and November of 1996 (Siedler and Zenk 1997) and the consecutive period until the recovery of moorings with the Japanese research vessel Hakuho Maru in March of 1998. 
TABLE 1. Flow statistics from moored observations. Angle brackets denote record average, and prime indicates deviation from the average. The east and north current components are given by $u$ and $v$, and $T$ is temperature. Stab gives the directional stability (avg vector speed/ avg scalar speed), and $\tau$ is the time scale (integral of autocorrelation function to first zero crossing).

\begin{tabular}{|c|c|c|c|c|c|c|c|c|c|c|c|c|c|}
\hline \multirow[b]{3}{*}{ Depth $(\mathrm{m})$} & \multirow{3}{*}{$\begin{array}{l}\text { Period } \\
\text { (days) }\end{array}$} & \multicolumn{3}{|c|}{ Mean } & \multicolumn{3}{|c|}{ Mean } & \multicolumn{3}{|c|}{ Std dev } & \multirow{2}{*}{\multicolumn{3}{|c|}{ Time scale (days) }} \\
\hline & & \multirow{2}{*}{$\begin{array}{c}\text { Speed } \\
\left(\mathrm{cm} \mathrm{s}^{-1}\right)\end{array}$} & \multirow{2}{*}{$\begin{array}{l}\text { Direction } \\
\left({ }^{\circ}\right)\end{array}$} & \multirow[b]{2}{*}{ Stab } & \multirow{2}{*}{\multicolumn{2}{|c|}{$\begin{array}{cc}\langle u\rangle & \langle v\rangle \\
\left(\mathrm{cm} \mathrm{s}^{-1}\right) & \left(\mathrm{cm} \mathrm{s}^{-1}\right)\end{array}$}} & \multirow{2}{*}{$\langle T\rangle\left({ }^{\circ} \mathrm{C}\right)$} & \multirow{3}{*}{$\begin{array}{c}u^{\prime} \\
\left(\mathrm{cm} \mathrm{s}^{-1}\right)( \\
\text { Mar } 1998\end{array}$} & \multirow{2}{*}{$\begin{array}{c}v^{\prime} \\
\left(\mathrm{cm} \mathrm{s}^{-1}\right)\end{array}$} & \multirow{2}{*}{$T^{\prime}\left({ }^{\circ} \mathrm{C}\right)$} & & & \\
\hline & & & & & & & & & & & $\tau_{u}$ & $\tau_{v}$ & $\tau_{T}$ \\
\hline \multicolumn{13}{|c|}{ V371 $\left(11^{\circ} 25.65^{\prime} \mathrm{N}, 138^{\circ} 43.60^{\prime} \mathrm{E}\right) 13$ Oct $1996-8$ Mar 1998} & \\
\hline 647 & 506 & 0.9 & 83 & 0.11 & 0.9 & 0.1 & 6.2 & 5.9 & 7.4 & 0.2 & 16 & 10 & 13 \\
\hline 3220 & 506 & 0.9 & 304 & 0.31 & -0.8 & 0.5 & 1.6 & 1.1 & 3.7 & 0.0 & 5 & 17 & 16 \\
\hline 3720 & 506 & 4.1 & 351 & 0.78 & -0.6 & 4.0 & 1.5 & 2.0 & 8.7 & 0.0 & 5 & 20 & 20 \\
\hline 4220 & 506 & 10.4 & 0 & 0.96 & 0.0 & 10.4 & 1.5 & 2.0 & 8.7 & 0.0 & 4 & 21 & 35 \\
\hline 4670 & 506 & 8.2 & 356 & 0.89 & -0.6 & 8.2 & 1.5 & 1.8 & 8.5 & 0.0 & 5 & 19 & 37 \\
\hline \multicolumn{14}{|c|}{ V372 $\left(12^{\circ} 6.00^{\prime} \mathrm{N}, 138^{\circ} 53.10^{\prime} \mathrm{E}\right) 14$ Oct $1996-8$ Mar 1998} \\
\hline 3140 & 505 & 1.0 & 45 & 0.31 & 0.7 & 0.7 & 1.6 & 2.6 & 2.5 & 0.0 & 11 & 13 & 35 \\
\hline 3640 & 114 & 4.7 & 23 & 0.79 & 1.9 & 4.3 & 1.6 & 2.6 & 5.2 & 0.0 & 10 & 9 & 8 \\
\hline 4140 & 505 & 3.9 & 356 & 0.76 & -0.3 & 3.9 & 1.4 & 3.3 & 3.2 & 0.0 & 10 & 9 & 12 \\
\hline 4580 & 438 & 6.8 & 320 & 0.95 & -4.4 & 5.2 & 1.5 & 4.4 & 3.3 & 0.0 & 13 & 12 & 19 \\
\hline \multicolumn{14}{|c|}{ V373 $\left(6^{\circ} 14.50^{\prime} \mathrm{N}, 153^{\circ} 43.50^{\prime} \mathrm{E}\right) 29$ Oct $1996-3$ Mar 1998} \\
\hline 1900 & 485 & 1.3 & 87 & 0.35 & 1.3 & 0.1 & 2.4 & 3.1 & 2.8 & 0.0 & 6 & 12 & 12 \\
\hline 2400 & 485 & 0.7 & 193 & 0.28 & -0.1 & -0.6 & 2.0 & 2.4 & 1.6 & 0.0 & 21 & 12 & 16 \\
\hline 2900 & 485 & 0.6 & 116 & 0.23 & 0.5 & -0.2 & 1.7 & 2.6 & 1.8 & 0.0 & 22 & 18 & 16 \\
\hline 3400 & 485 & 1.5 & 84 & 0.35 & 1.5 & 0.2 & 1.6 & 4.5 & 2.6 & 0.0 & 15 & 15 & 20 \\
\hline 4041 & 485 & 0.1 & 207 & 0.25 & 0.0 & -0.1 & 1.5 & 0.3 & 0.3 & 0.0 & 10 & 13 & 21 \\
\hline \multicolumn{14}{|c|}{ V374 $\left(8^{\circ} 38.60^{\prime} \mathrm{N}, 150^{\circ} 56.90^{\prime} \mathrm{E}\right) 27$ Oct $1996-4$ Mar 1998} \\
\hline 740 & 461 & 0.5 & 313 & 0.13 & -0.4 & 0.4 & 5.9 & 3.9 & 3.1 & 0.1 & 34 & 13 & 28 \\
\hline 2830 & 485 & 0.5 & 324 & 0.18 & -0.3 & 0.4 & 1.7 & 2.0 & 2.9 & 0.0 & 21 & 18 & 27 \\
\hline 3330 & 485 & 1.9 & 220 & 0.40 & -1.2 & -1.4 & 1.5 & 2.7 & 4.5 & 0.0 & 21 & 28 & 19 \\
\hline 3830 & 485 & 5.4 & 209 & 0.74 & -2.6 & -4.7 & 1.6 & 3.2 & 6.2 & 0.0 & 30 & 29 & 25 \\
\hline 4270 & 485 & 4.9 & 199 & 0.83 & -1.6 & -4.6 & 1.5 & 1.8 & 5.2 & 0.0 & 21 & 25 & 29 \\
\hline
\end{tabular}

Hydrographic sections used here cross the East Mariana and the East Caroline Basins (Figs. 2 and 15). Moored current-meter observations were performed at four selected sites that were chosen on the basis of surveys with an STN Atlas Marine Electronics, GmbH, "Hydrosweep" DS multibeam echosounder system. Data processing of the echosounder data will be described later in the context of interbasin exchange. The mooring positions were on the ridges between the West and East Mariana Basins (V371, V372) and between the East Mariana and East Caroline Basins (V373, V374). The positions, deployment periods, and flow statistics of the mooring data are given in Table 1 .

\section{Deep-water distributions}

\section{a. Watermass properties}

First we want to find the optimal choice of property values identifying the boundary between LCPW and NPDW in this particular region and to examine the watermass distributions in the East Mariana and East Caroline Basins and in the sill areas that are critical for deep-water exchange. Somewhat different values had been used by various authors as indicators of the watermass boundaries between NPDW and LCPW. Wijffels et al. (1998) selected the neutral surface $28.11 \mathrm{~kg}$ $\mathrm{m}^{-3}$ along $149^{\circ} \mathrm{E}$ to separate these water masses. Their corresponding section-averaged potential temperature $\Theta$ was $1.07^{\circ} \mathrm{C}$. Johnson and Toole (1993) used $\Theta=1.2^{\circ} \mathrm{C}$ for a large western Pacific region, and Johnson et al. (1994) also took $\Theta=1.2^{\circ} \mathrm{C}$ in the Samoan Passage. Klatt and Holfort (2000) selected $\Theta=1.1^{\circ} \mathrm{C}$, oxygen $\mathrm{O}_{2}=170 \mu \mathrm{mol} \mathrm{kg}{ }^{-1}$, silicate $\mathrm{SiO}_{4}=136 \mu \mathrm{mol} \mathrm{kg}{ }^{-1}$, and salinity $S=34.670$ in their tracer study in the East Mariana Basin.

We will use the silicate distributions in the sections (Figs. 3 and 4) to select the boundary between NPDW and LCPW. A high-silicate tongue with maximum values above $144 \mu \mathrm{mol} \mathrm{kg} \mathrm{kg}^{-1}$ at about 2500-3500 m marks the core of the NPDW. The lower boundaries of the tongues in the sections are found near $4000 \mathrm{~m}$ in the East Mariana Basin and approximately correspond to isolines of $\Theta_{3}=1.4^{\circ} \mathrm{C}$ ( or $\Theta=1.18^{\circ} \mathrm{C}$, close to the $1.2^{\circ} \mathrm{C}$ used by several other authors), $S=34.685, \sigma_{3}$ $=41.5, \mathrm{O}_{2}=155 \mu \mathrm{mol} \mathrm{kg}{ }^{-1}$, and $\mathrm{SiO}_{4}=142 \mu \mathrm{mol}$ $\mathrm{kg}^{-1}$. In property plots (Fig. 5), these values mark the transition from low to increasing scattering of points. In Fig. 3 we recognize a region of cold water off the bottom in the East Mariana Basin, marking the core of the LCPW. A corresponding high-oxygen, high-salinity, and low-silicate pattern is found, and phosphate and nitrate distributions have corresponding minima in the core region (not shown). We find densities above $\sigma_{3}=$ 41.5 or temperatures below $\Theta_{3}=1.4^{\circ} \mathrm{C}$ on both sides of the ridge, indicating an LCPW flow from the East Mariana to the East Caroline Basin above a sill near 

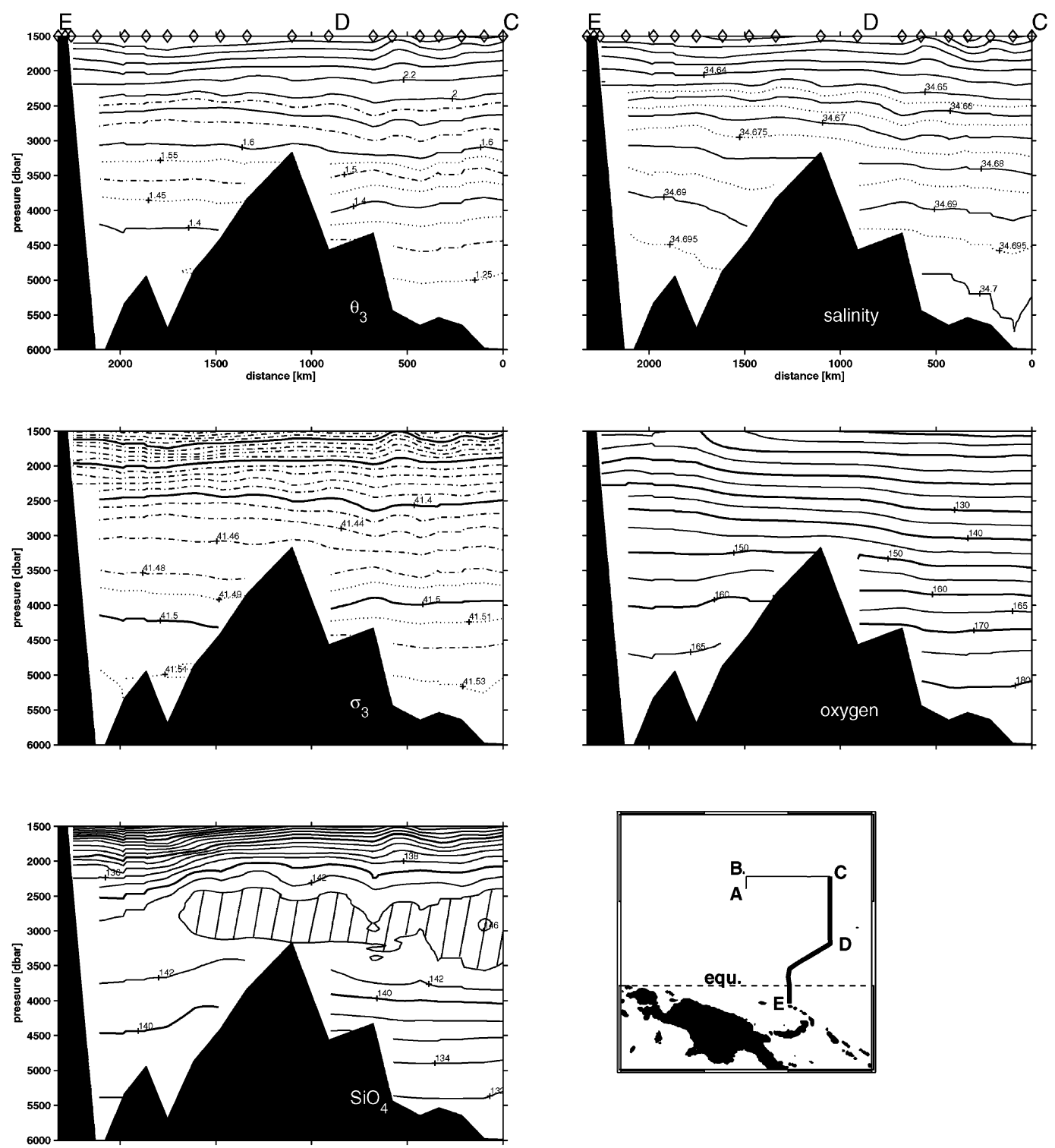

FIG. 3. The "meridional section:" potential temperature $\Theta_{3}$ (referenced to $3000 \mathrm{dbar},{ }^{\circ} \mathrm{C}$ ), salinity, density $\sigma_{3}$, oxygen $\left(\mu \mathrm{mol} \mathrm{kg}{ }^{-1}\right)$, and silicate $\mathrm{SiO}_{4}\left(\mu \mathrm{mol} \mathrm{kg}{ }^{-1}\right)$. The core of the silicate maximum is hatched. The location of section $\mathrm{C}-$ $\mathrm{D}-\mathrm{E}$ is indicated on the map in the lower right corner (see also Fig. 2). Tick marks give station locations. The equator is located in the southern part of the East Caroline Basin.

4200-4300-m depth. The oxygen, nutrient, and salinity distributions are again consistent with this conclusion.

LCPW properties are found all along the section in Fig. 4, with a somewhat elevated upper boundary in a broad range in the middle part of the basin. The silicate maximum of NPDW reaches as far as the western part of the section. Local maxima of silicate are recognized to the right and also to the left of the vertical line at B, suggesting a spreading of NPDW from the north across the zonal subsection and then to the west across the short meridional subsection. Both in salinity and in oxygen we recognize opposing slopes on both sides of this corner in the section, with another smaller change in slope at the southern (left side) end of the meridional part. This pattern corresponds to the density distribution and suggests deep-water geostrophic transport.

\section{b. Geostrophic flow}

We want to estimate geostrophic currents in the deep water of the East Mariana Basin across the lines A-BC-D (see Fig. 3). Reference levels near 3600 dbar were earlier used in the larger region. However, the current regime in the East Mariana Basin will be controlled well by bottom topography, enforcing an inflow-outflow balance below the critical sill depth at the YMJ in the box 

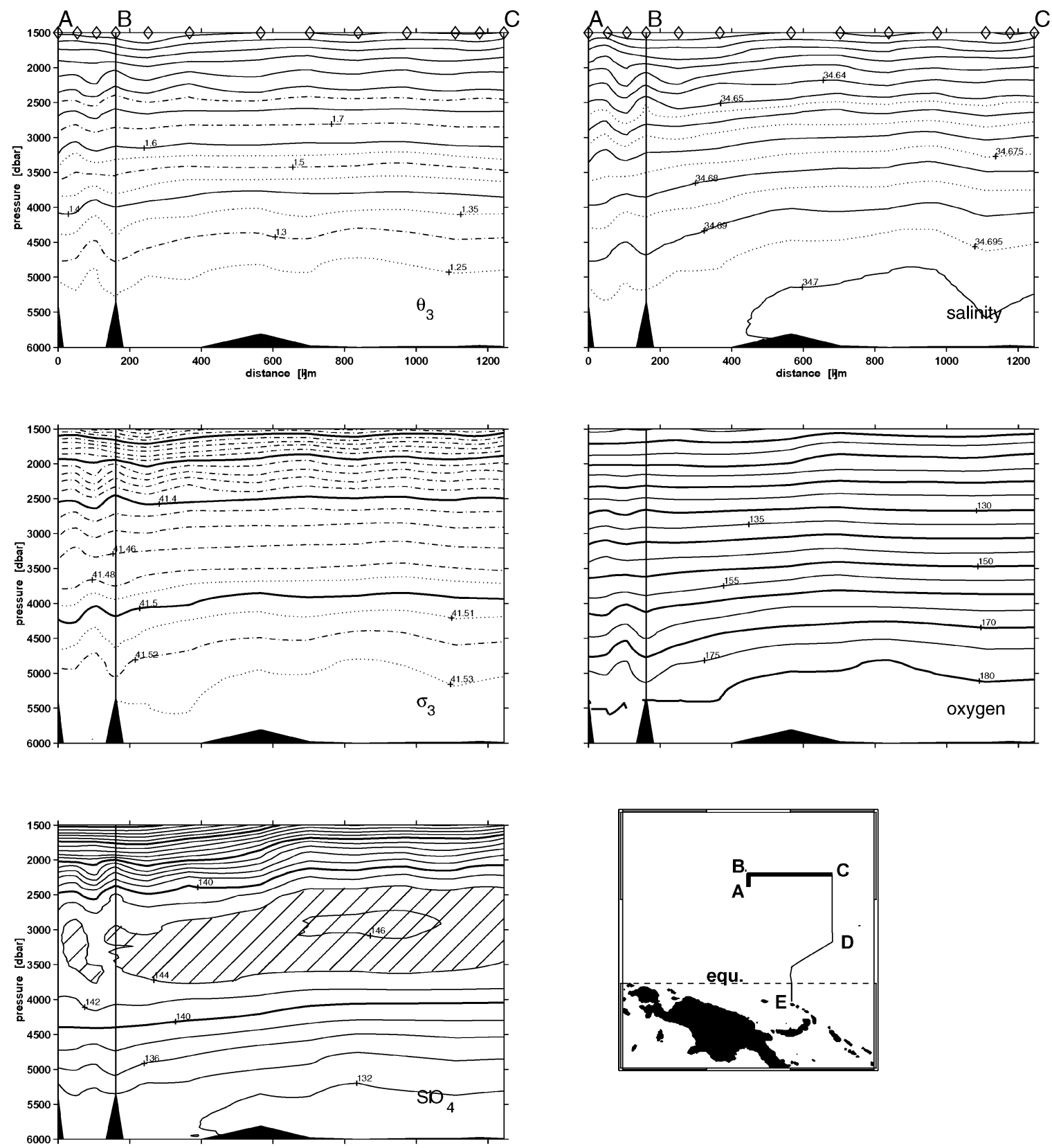

FIG. 4. The "zonal section": potential temperature $\Theta_{3}\left({ }^{\circ} \mathrm{C}\right)$, salinity, density $\sigma_{3}$, oxygen $\left(\mu \mathrm{mol} \mathrm{kg}{ }^{-1}\right)$, and silicate $\mathrm{SiO}_{4}\left(\mu \mathrm{mol} \mathrm{kg}{ }^{-1}\right)$. The core of the silicate maximum is hatched. The location of section A-B-C is indicated on the map in the lower-right corner (see also Fig. 2). Tick marks give station locations. The vertical line at B marks the transition from the long zonal to the short meridional part of the section.

given by our sections and the Mariana Ridge, and probably with weaker currents than above. We therefore tried to use somewhat deeper reference levels, which corresponded either to the sill depth or to the potential density at this level near the sill. In both cases rather large transports in and out of the deeper basin occurred. Varying the reference level led us to the conclusion that a weak deep circulation with vertically increasing transports just above sill level was best represented when using a much deeper level in the basin. We therefore selected a level of $5500 \mathrm{dbar}$ as reference (Fig. 6). This depth is well below the sill depths of the two ridges under discussion but above the bottom in most of the East Mariana Basin.

Most of the LCPW and NPDW enters the box from the north in the western part of the zonal section. Some narrow current patterns are found at the western end of the short meridional subsection. Both water masses move with an eastward current component between the two station pairs in the southern part of the short me- 

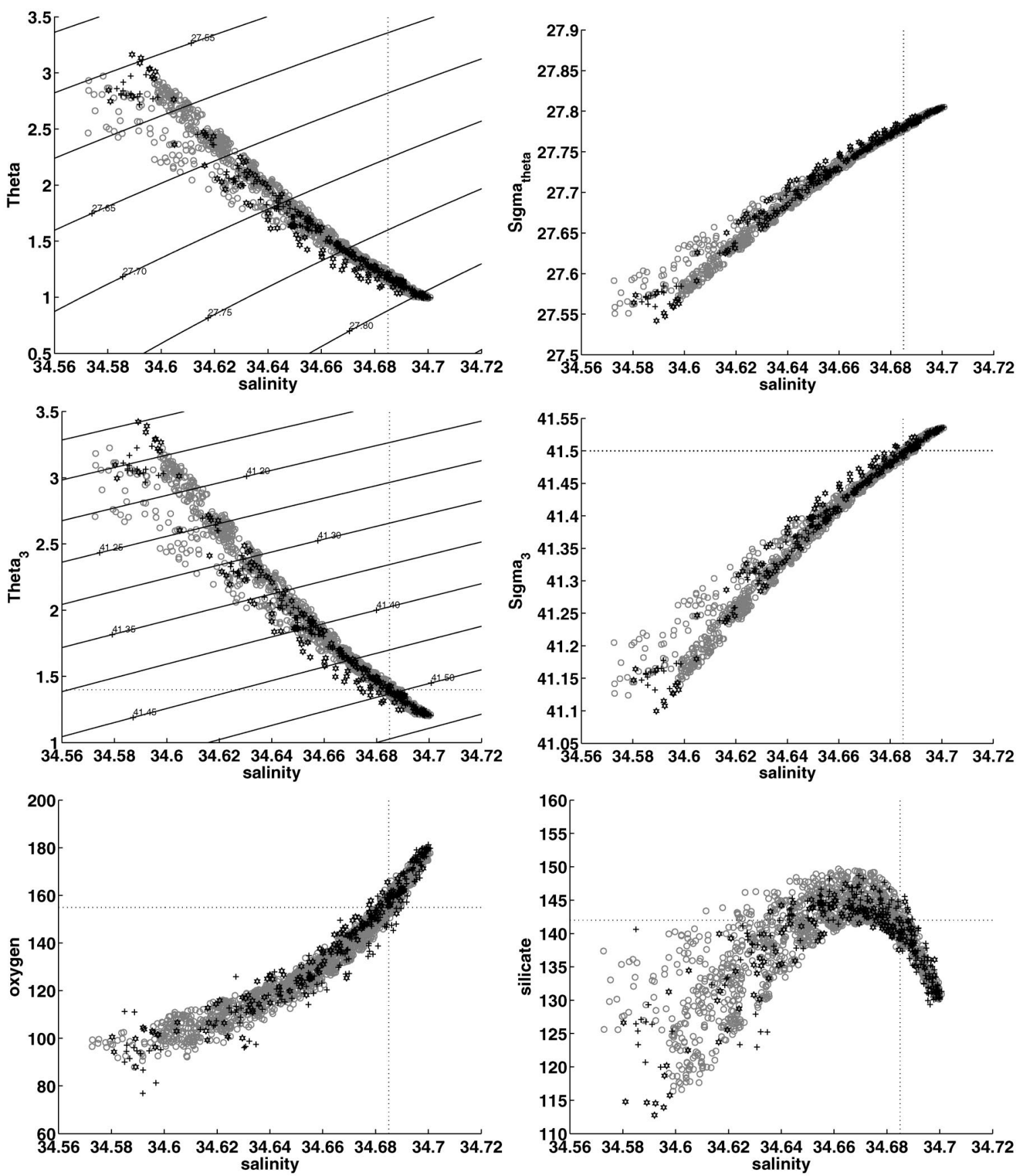

FIG. 5. Properties vs salinity in the deep water: potential temperature Theta (referenced to the surface, ${ }^{\circ} \mathrm{C}$ ), density parameter Sigma ${ }_{\text {theta }}$ $\left(\mathrm{kg} \mathrm{m}^{-3}\right)$, potential temperature Theta ${ }_{3}$ (referenced to $3000 \mathrm{dbar},{ }^{\circ} \mathrm{C}$ ), density parameter Sigma ${ }_{3}\left(\mathrm{~kg} \mathrm{~m}^{-3}\right)$, oxygen $\left(\mu \mathrm{mol} \mathrm{kg}^{-1}\right)$, and silicate $\left(\mu \mathrm{mol} \mathrm{kg}{ }^{-1}\right)$. The dotted lines indicate the selected watermass boundary values. Circles represent data south of $20^{\circ} \mathrm{N}$ from WOCE P04, P09, and P10. Crosses are TROPAC data from the southern East Mariana Basin. Stars are TROPAC data south of Guam and in the East Caroline Basin. Isolines of Sigma 3 are given in the $\mathrm{Sigma}_{3} / \mathrm{salinity}$ figure.

ridional subsection along $145^{\circ} 00^{\prime} \mathrm{E}$ and with a westward component near the corner point. Close to the western end of the zonal subsection along $12^{\circ} 54^{\prime} \mathrm{N}$, the current has a southward component. This pattern suggests a loop current east of Guam, from the north across the zonal subsection, to the west in the northern part of the short meridional subsection, and partly returning to the east in the southern part of the short meridional subsection. The pattern is apparently topographically controlled and may well be a persistent property of the flow.

Kawabe et al. (2003) recently published a study of the larger-scale deep-water circulation in the low-lati- 

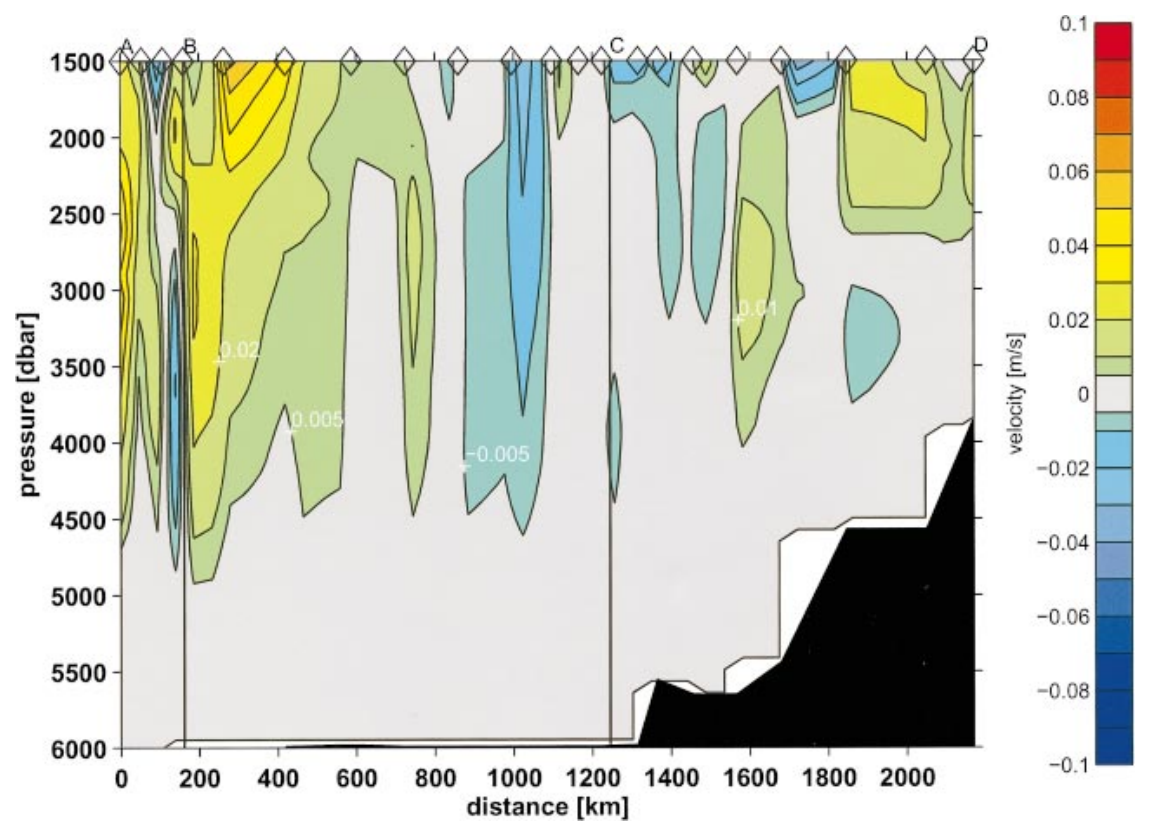

FIG. 6. Geostrophic currents normal to the three subsections A-B-C-D (see Fig. 2), with assumed reference level at 5500 dbar. Positive values represent directions into the southern East Mariana Basin. Gray background indicates velocities below $0.5 \mathrm{~cm} \mathrm{~s}^{-1}$. Tick marks give station locations.

tude western North Pacific, including also new hydrographic data at $140^{\circ}$ and $150^{\circ} \mathrm{E}$, west and east of the IOMR. They used watermass properties to determine the flow pattern and the shallower reference level of the $1.3^{\circ} \mathrm{C}$ surface for geostrophic calculations. The overall transport pattern of the LCPW in their study is consistent with the pattern that we obtain in the southern East Mariana Basin, with a southward western boundary transport east of Guam and a branching into a westward transport to the West Mariana Basin and an eastward return transport. However, their transport numbers are somewhat larger than those given below.

With the assumption of synopticity in the deep layers, we calculate the mass transports across the three parts $\mathrm{A}-\mathrm{B}, \mathrm{B}-\mathrm{C}$, and $\mathrm{C}-\mathrm{D}$ (Fig. 7), given in teragrams per second, which corresponds to a sea water volume transport of $1 \mathrm{~Sv}$ within a few percent. The effects of reference level choice usually dominate the transport errors in the deep water. Changing the reference level from 5500 to 6000 dbar results in mass transport changes that are usually less than $0.2 \mathrm{Tg} \mathrm{s}^{-1}$, and we assume an uncertainty of $0.3 \mathrm{Tg} \mathrm{s}^{-1}$ at the LCPW levels. Subsection transports are zero within this error limit in the two deepest layers between $\sigma_{3}=41.54$ and 41.52, as expected for a basin that is closed by the Caroline Ridge in the south and by the three subsections at the other three sides.

The two layers farther above, between 41.52 and 41.50 , describe the part of the LCPW that can cross the critical sills. We find inflow from the north and outflow to the west; $1.95 \mathrm{Tg} \mathrm{s}^{-1}$ of LCPW arriving from the
Marshall Islands slope is guided by bottom topography to enter the box from the north, and $0.55 \mathrm{Tg} \mathrm{s}^{-1}$ leave toward the West Mariana Basin. The net transport in these two layers, including all three subsections, amounts to $1.3 \mathrm{Tg} \mathrm{s}^{-1}$, which has to upwell into shallower layers or to cross the Caroline Ridge to the south to close the budget. The transport pattern in Fig. 7 also shows the inflow of NPDW from the north, mostly crossing the basin to the south.

\section{Interbasin exchange}

\section{a. Approach}

One aim of the TROPAC experiment was to identify deep-water throughflow regions, in particular between the East and West Mariana Basins and between the East Mariana and East Caroline Basins. Neither ship time nor available equipment permitted placement of extensive arrays of moorings in sill regions. Studies were therefore restricted to identifying critical sill areas with the multibeam echosounder system, placing one mooring each in suspected sill areas with current and temperature meters at near-bottom levels, and performing one hydrographic station for watermass identification and moored temperature sensor calibration checks near the mooring position after deployment.

Also, ship-time limitations prevented systematic echosounding surveys. On the basis of then available General Bathymetric Chart of the Oceans (GEBCO) data (Jones et al. 1994), we identified the areas where critical 


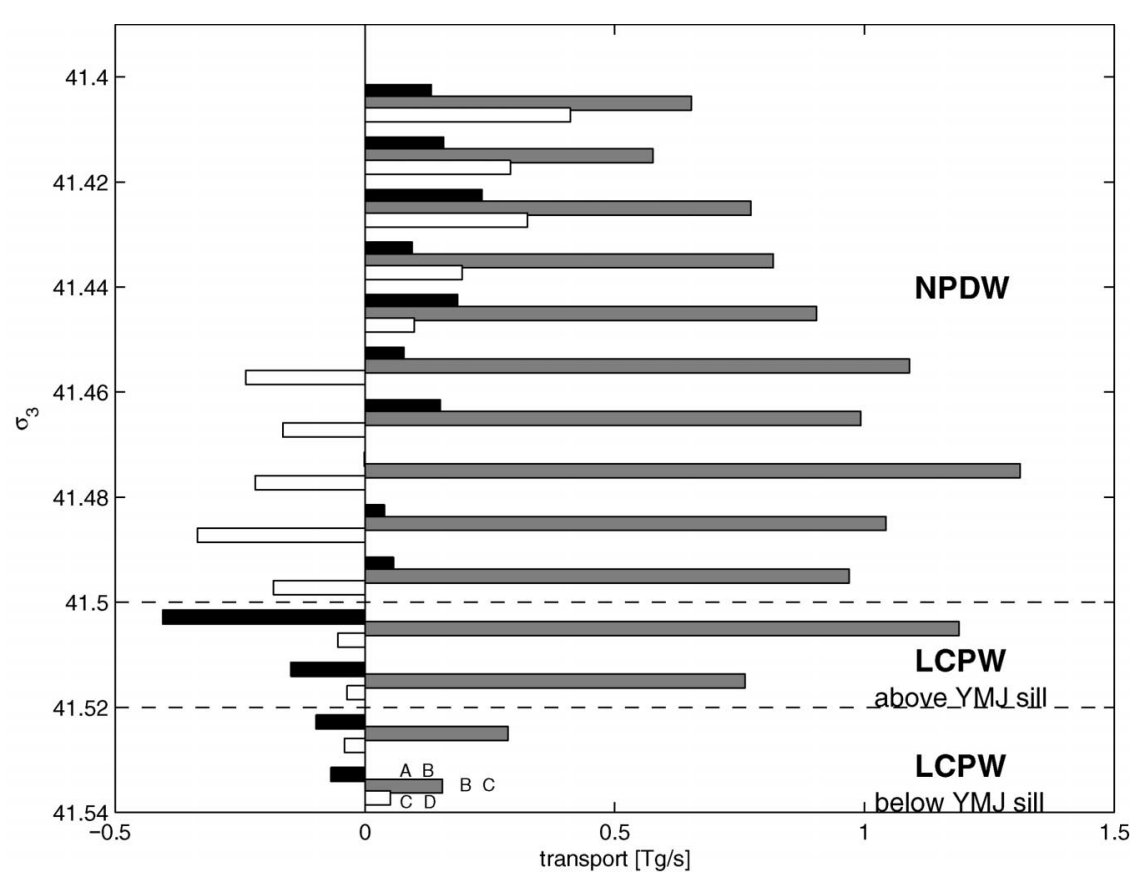

FIG. 7. Geostrophic mass transports in layers between isopycnal $\left(\sigma_{3}\right)$ surfaces for the three subsections A-B-C-D (see Fig. 2), with assumed reference level at 5500 dbar. Black: subsection A-B. Gray: subsection B-C. White: subsection C-D. Positive values represent directions into the southern East Mariana Basin.

sills could be expected. Note, however, that reliable deep bottom data were scarce for this region at the time. Major deviations were found between echosounder and GEBCO data (and even more so the nautical chart data). In the case of the transition between the East and West Mariana Basins, after identifying the probable area in the YMJ, we tried to find the critical sill by approximately following isobaths along the ridge. We placed the first mooring (V371, Yap Trench) at a position where we thought to have found the entrance to the sill area, but we realized the next day that we were still at the ridge slope (Fig. 2). Additional echosounding then led us to the actual throughflow area where the second mooring (V372, YMJ) was placed.

On the ridge between the East Mariana and East Caroline Basins, we had identified two possible sill areas from precruise data. Because of the more limited extensions of these areas, we were able to perform systematic Hydrosweep soundings, although not with optimum resolution and extension. Nevertheless, the sill regions were clearly identified. We placed the third mooring (V373, Losap) in the sill area in the east near the Losap Atoll and the fourth mooring (V374, East Fayu) in the sill area farther west near East Fayu. The western entrance was deeper and appeared to have the controlling deep-water sill.

In addition to the automatic treatment of multibeam echosounder data performed during the observations, the depth (travel time) data were later reanalyzed using the MultiBeam (MB)-System software package from the
Lamont-Doherty Earth Observatory. Vertical sound velocity profiles from neighboring TROPAC CTD stations, complemented by historical Levitus data at greater depth (Levitus et al. 1994a,b), were applied. In addition to automatic inspection and error correction provided by the software package, the individual across-track depth profiles were also interactively edited to eliminate anomalous data. The resulting maps were subsequently compared with topographies from satellite altimeter data (Smith and Sandwell 1997).

Overall we find a good correspondence in topographic structure between the echosounder and the altimeter results (Fig. 8). The echosounder topographies, however, are less smoothed and therefore often give somewhat greater depth values in deep troughs or near slopes. The critical throughflow areas were identified, and sill depths were determined from the echosounder topographies when available and otherwise from altimeter bottom topographies. The resulting sill positions and depths in the monitored regions are summarized in Table 2.

With the complex trench and ridge topography near the YMJ the question arises as to whether there may be other areas with throughflow to the West Mariana Basin. The later discussion of currents from moorings will show that the location close to mooring V372 clearly is a throughflow area for the LCPW. The conclusion that this is also the region with the critical sill is supported by the currents at mooring V371 farther south at the ridge slope where a strong and directionally stable flow of LCPW to the north is observed along the slope (Fig. 
A)
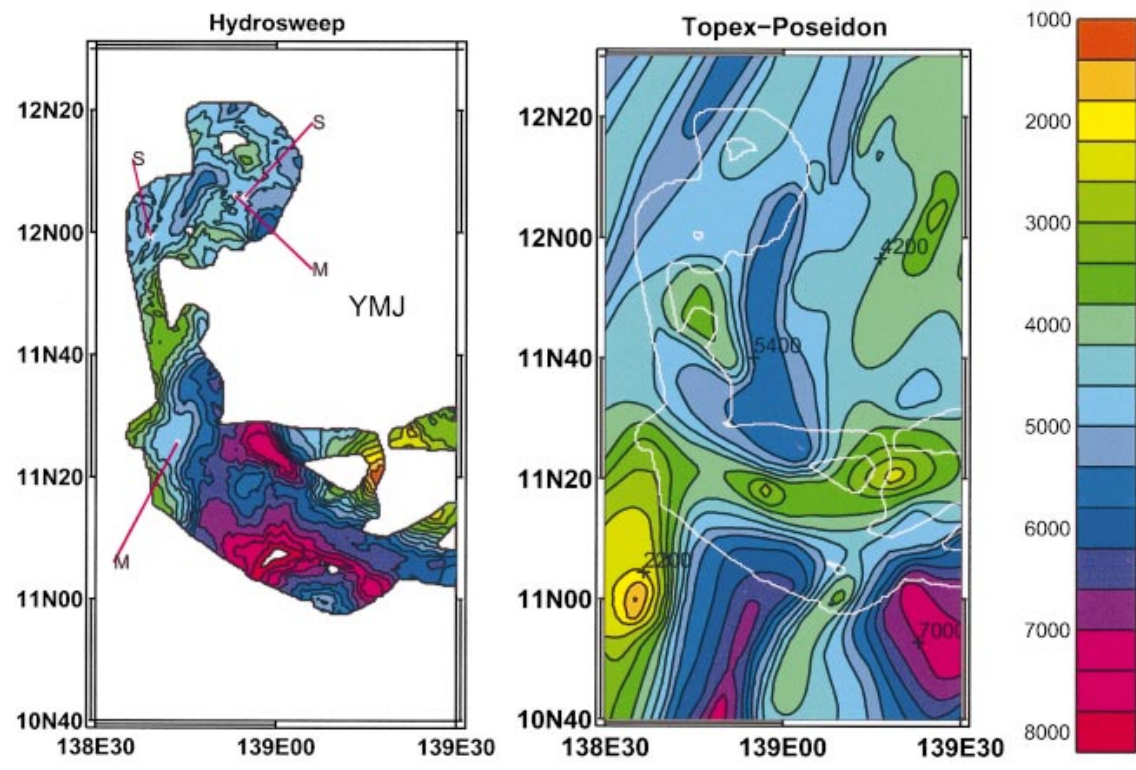

B)
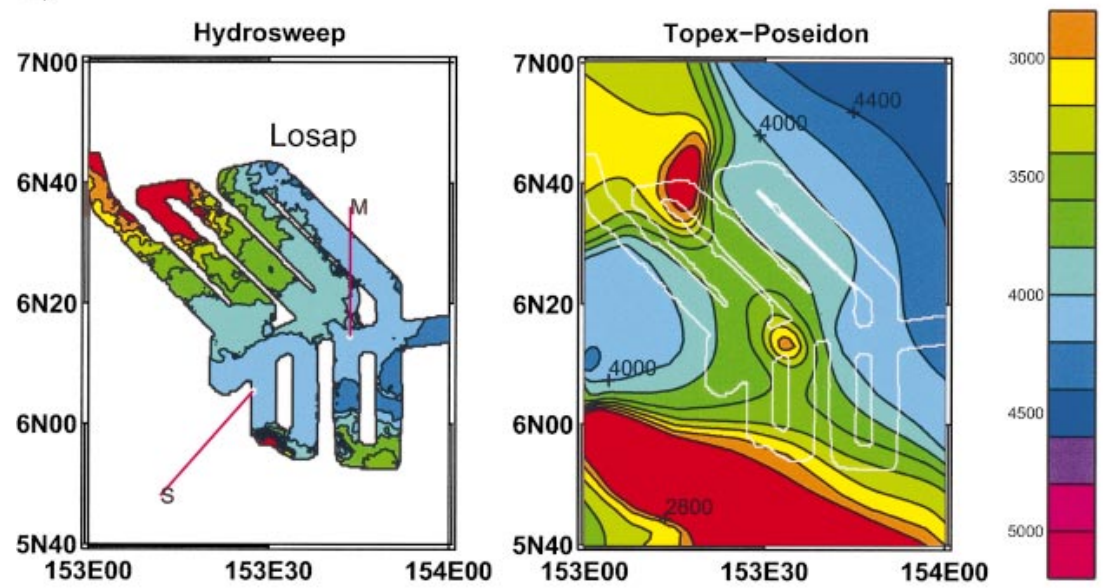

C)
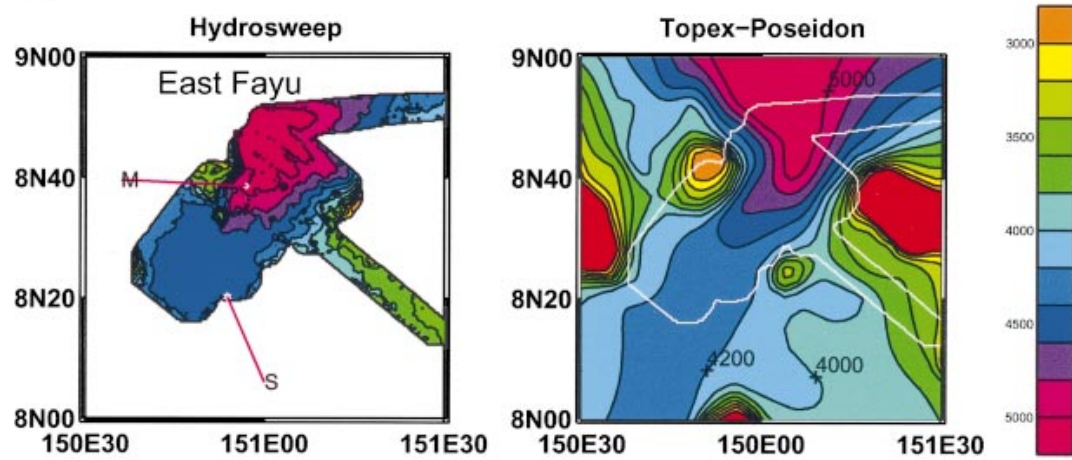

FIG. 8. Maps obtained from (left) Hydrosweep multibeam echo sounding and from (right) Ocean Topography Experiment (TOPEX)/Poseidon satellite altimetry (Smith and Sandwell 1997): (a) in the transition between the East and West Mariana Basins (YMJ in northern part), (b) in the eastern transition (Losap) between the East Mariana and East Caroline Basins, and (c) in the western transition (East Fayu) between the East Mariana and East Caroline Basins. The outer boundaries of the echosounder maps on the left are repeated as white lines in the altimeter maps on the right. Mooring positions (M) and sills (S) are indicated in the maps on the left side. Please note that the color codes differ between (a) and (b), (c). 
TABLE 2. Depths and positions of critical sills (see text).

\begin{tabular}{|c|c|c|c|c|}
\hline \multirow[b]{2}{*}{ Sill area } & \multirow[b]{2}{*}{ Mooring No. } & \multicolumn{2}{|c|}{ Position } & \multirow[b]{2}{*}{ Depth (m) } \\
\hline & & Lat & Lon & \\
\hline \multirow[t]{2}{*}{ Yap-Mariana Junction } & Close to V372 & $12^{\circ} 06^{\prime} \mathrm{N}$ & $138^{\circ} 55^{\prime} \mathrm{E}$ & 4875 \\
\hline & Southwest of V372 & $11^{\circ} 59^{\prime} \mathrm{N}$ & $138^{\circ} 39^{\prime} \mathrm{E}$ & 4630 \\
\hline Losap & Close to V373 & $06^{\circ} 05^{\prime} \mathrm{N}$ & $153^{\circ} 27^{\prime} \mathrm{E}$ & 4080 \\
\hline East Fayu & Close to V374 & $08^{\circ} 20^{\prime} \mathrm{N}$ & $150^{\circ} 54^{\prime} \mathrm{E}$ & 4440 \\
\hline
\end{tabular}

9 and Table 1). However, although the position of V372 is apparently in the throughflow channel, it is not at the shallowest sill, which, according to the echosounder data, appears to be located somewhat to the southwest at $4630 \mathrm{~m}$ (Fig. 10a and Table 2). Water mass distributions suggest a somewhat shallower sill depth (Fig. 4).

The important sill area at the Caroline Ridge is found in the throughflow region at East Fayu in Fig. 8c. The echosounding covered the approach to the sill, and the satellite-derived map suggests that the sill itself is found just to the west of the area covered by the Hydrosweep observations. However, despite being certain that the key throughflow region was detected, we cannot be quite sure that the shallowest sill in this area was found. The hydrographic data had suggested a sill depth between about 4200 and $4300 \mathrm{~m}$, whereas our suggested sill depth is at $4440 \mathrm{~m}$ (Table 2).
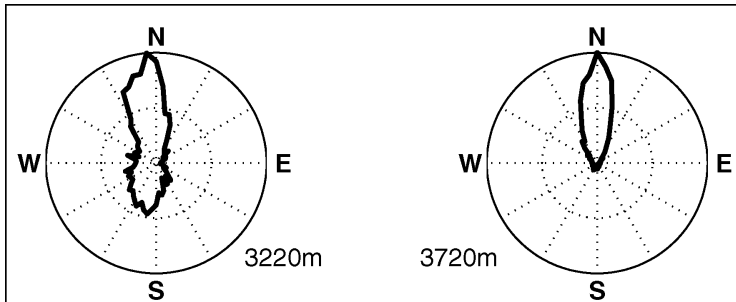

V371
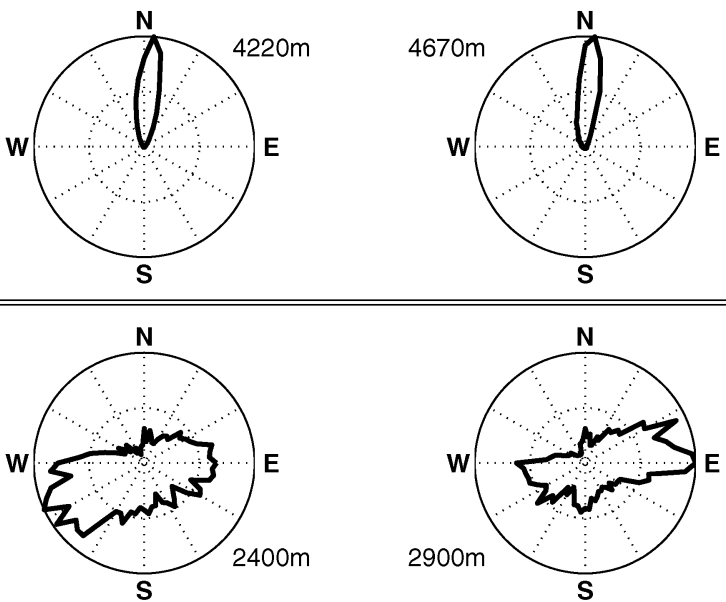

V373
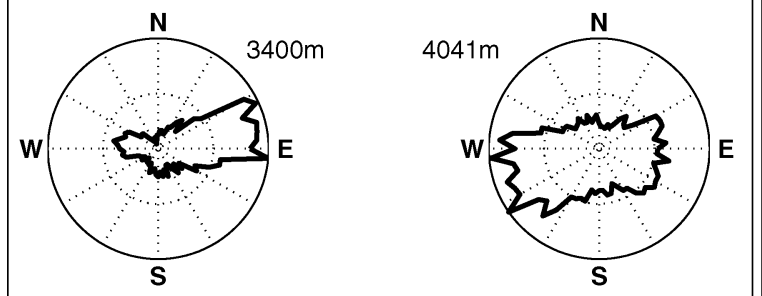

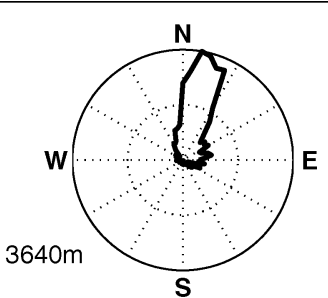

V372
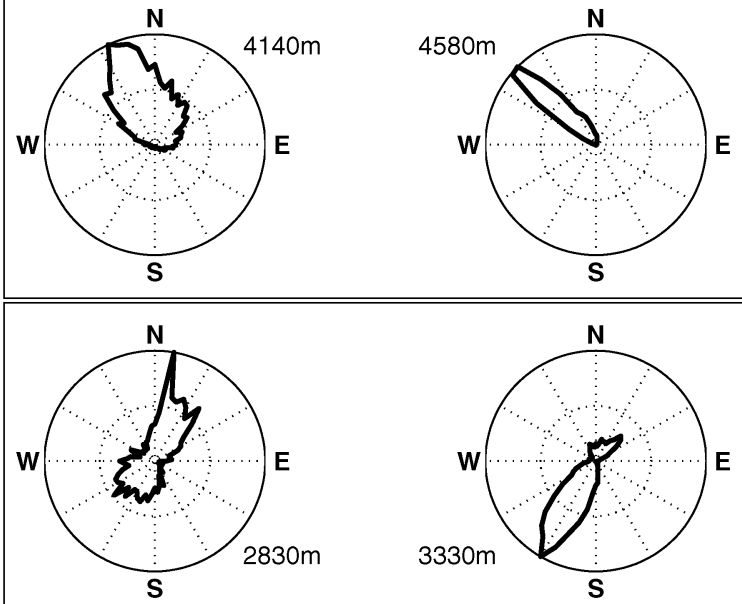

V374
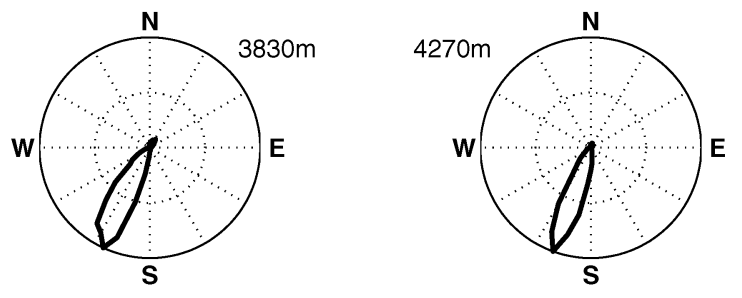

FIG. 9. Normalized frequency distributions of transports from the deep instruments in moorings V371, V372, V373, and V374. Current vectors are sorted into $5^{\circ}$ ranges, and velocities for each time step are added in each of these ranges, corresponding to the frequency of transports. 

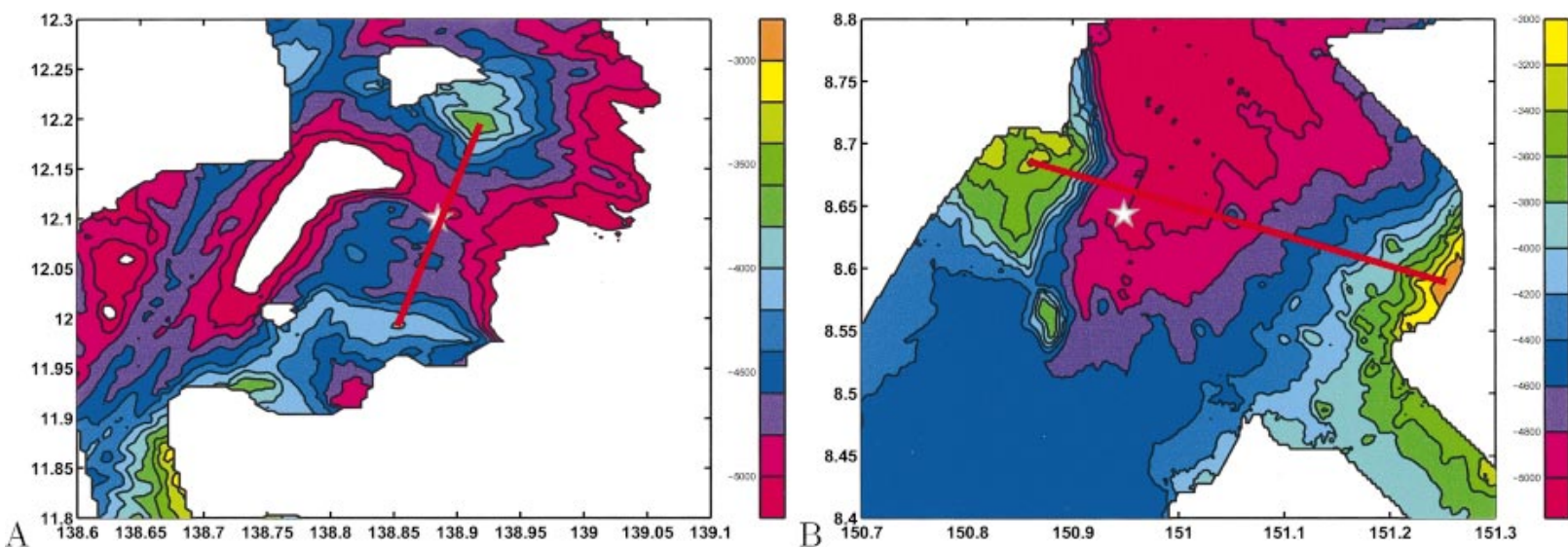

FIG. 10. Topography in the sill regions: (a) between the East and West Mariana Basins (mooring V372, Yap-Mariana Junction), and (b) between the East Mariana and the East Caroline Basins (mooring V374, East Fayu). The stars give mooring positions, and the red lines indicate the selected cross sections for transport estimation.

In the moorings, Aanderaa current meters carried speed, direction, and temperature sensors, with the uppermost instrument additionally containing a pressure sensor to monitor mooring inclination. Assuming a rigid inverted pendulum, it was confirmed that mooring inclination was sufficiently small to be sure that temperature changes in the deep time series could be interpreted as watermass changes.

\section{b. Properties of flow}

Are the transports consistent with flows through deep channels? The normalized frequency distributions of transports (Fig. 9) clearly show patterns that are typical for topography-guided throughflow. At the YMJ, mooring V372 (YMJ) was obviously launched in a deep channel connecting the East and West Mariana Basins. Well above sill depth at $3140 \mathrm{~m}$ the transports vary strongly in direction. Directional stability grows with increasing depth, and the two instruments below $4000 \mathrm{~m}$ show an orientation to the northwest in the deep-channel direction, with high directional stability near the bottom.

At the Caroline Ridge, the throughflow from the East Mariana to the East Caroline Basin is recognized at V374 (East Fayu), where a mostly southwestward transport is recognized at $3330 \mathrm{~m}$ and a southwestward, directionally very stable transport is seen at the two instruments closest to the bottom. Although some preference in east-west orientation is seen at the other mooring V373 (Losap) at the Caroline Ridge, no indication exists there for a bottom-guided flow with high directional stability.

\section{c. Transports and mixing}

It would have required an array of moorings per channel and a pattern of hydrographic stations to determine volume transports. Just for a check on order of magnitude, we use the mean currents obtained from moor- ings V372 (YMJ) and V374 (East Fayu) together with information from the single hydrographic profiles near the moorings to calculate mean transports. We take the topographic information from the Hydrosweep surveys to determine representative cross sections (Fig. 10). Cross-sectional areas for 50-m-depth intervals were multiplied with the linearly interpolated mean moored velocities normal to the section. This corresponds to the assumption that the mooring was in the middle of the channel with linearly changing cross-stream isopycnals. Integrating from the bottom, we obtain cumulative transports. With integration up to the transport direction reversal at $3800 \mathrm{~m}$, we find $0.39 \mathrm{~Sv}$ at mooring V372 (YMJ) and $0.81 \mathrm{~Sv}$ at V374 (East Fayu). With integration to $4000 \mathrm{~m}$, corresponding to the earlier chosen boundary between NPDW and LCPW, we obtain 0.36 and $0.45 \mathrm{~Sv}$, respectively. Considering the limitations of this rough guess, the agreement with the earlier geostrophic transports is surprisingly good.

Johnson and Toole (1993) arrived at a LCPW transport of 5.6 Sv in the East Mariana Basin, mostly continuing northward. They suggested that a small amount of this water supplies the bottom water to the Philippine Basin through the Mariana Trench south of Guam. We find that about $1 \mathrm{~Sv}$ is lost from this northward flow, partly as flow to the West Mariana and Philippine Basins and partly to the East Caroline Basin where the inflow needs to be balanced by diapycnal exchange because of the closed basin below about $4000 \mathrm{~m}$.

To obtain an estimate of the average diffusion coefficient for this exchange, we assume that the volume transport ( $3800 \mathrm{~m}$ to the bottom at the sill) into the East Caroline Basin through the channel at East Fayu is balanced by uniform upwelling in the basin. The preservation of the mean temperature distribution in the basin is achieved by downward diffusion of heat through the upper boundary at about $3800 \mathrm{~m}$, balancing the supply of colder water from the inflow [see Hogg et al. (1982, 1994) for a similar case]. The related density surface 

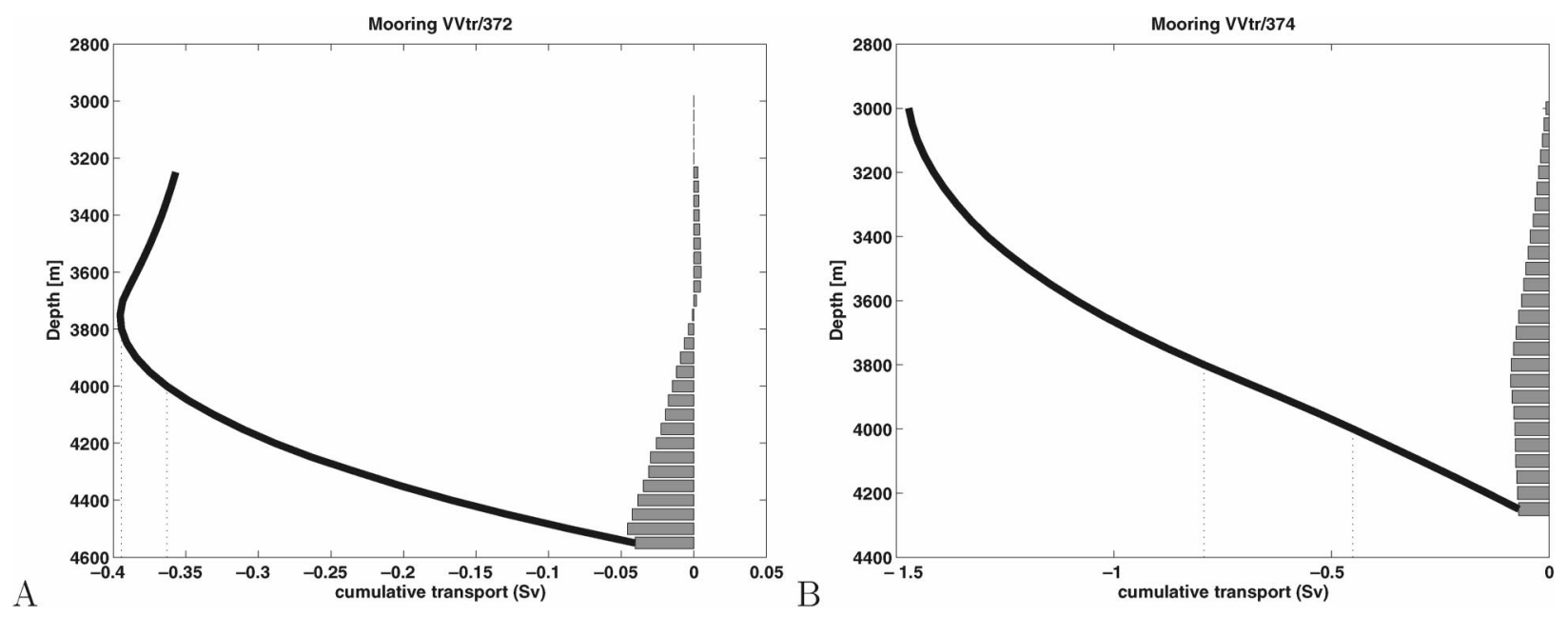

FIG. 11. Layer transports (gray bars) and cumulative transports (solid line): (a) between the East and West Mariana Basins (mooring V372, Yap-Mariana Junction), and (b) between the East Mariana and the East Caroline Basins (mooring V374, East Fayu) with cross sections as given by the red lines in Fig. 10. Transports are calculated from the bottom upward across each section. Negative values give transports out of the East Mariana Basin. The vertical dotted lines mark cumulative transports for integration up to 3800 or $4000 \mathrm{~m}$, respectively.

appears to be close to horizontal, and the vertical exchange therefore will be essentially diapycnal (Fig. 3).

We determined a mean upwelling velocity of close to $1 \times 10^{-6} \mathrm{~m} \mathrm{~s}^{-1}$ from the mooring V374 inflow volume transport (Fig. 11b) and the horizontal surface area covering depths $>4000 \mathrm{~m}$ in the East Caroline Basin. Using the vertical diffusion equation with (i) temperatures $\Theta_{3}$ from CTD station 113034 (Siedler and Zenk 1997) in the vicinity of mooring V374 for the upper

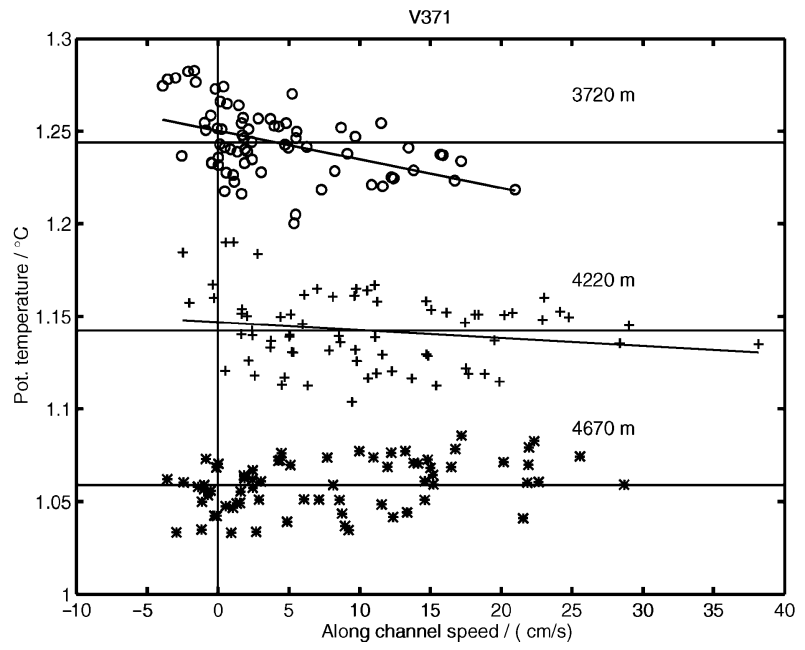

FIG. 12. Potential temperatures (referenced to the surface) vs weekly values of along-channel speeds for mooring V371 (Yap Trench). Values are only given from depths where records are longer than 438 days and where directional stabilities are larger than 0.7 (see Table 1). Positive velocities in this case correspond to the predominant nearbottom flow direction from the East Mariana Basin to the neighboring basins. Temperatures from current meters were adapted to CTD cast values obtained during mooring recovery. Straight horizontal lines give mean temperatures for the total record. Inclined lines represent straight-line fits. and lower boundaries of the layer between 3800 and $4500 \mathrm{~m}$, which will be most strongly influenced by the inflowing water; (ii) a mean vertical temperature gradient over $700 \mathrm{~m}$ centered at $3800 \mathrm{~m}$; and (iii) gradient changes determined from similar mean vertical gradients around the two depths $3800 \pm 350 \mathrm{~m}$, we obtained a heat diffusion coefficient of $15 \times 10^{-4} \mathrm{~m}^{2} \mathrm{~s}^{-1}$ (or 15 $\mathrm{cm}^{2} \mathrm{~s}^{-1}$ ). Given the large uncertainties in such an estimate, this value is close to the $5 \mathrm{~cm}^{2} \mathrm{~s}^{-1}$ given by Hogg et al. (1994) for the deep Brazil Basin but is lower by about one order of magnitude than most values known for deep passages (Hogg 2001).

\section{d. Variability}

Are the throughflow changes correlated with watermass property changes? Near sill depths, horizontal temperature gradients exist from one basin to the other, and the temperatures increase from the East Mariana Basin toward the West Mariana Basin and in a corresponding way toward the East Caroline Basin. Increasing throughflow can then be expected to advect colder water and might be recognized in diagrams of temperature anomalies versus along-channel speeds (Figs. 12-14).

A particular feature is apparent at V371 (Yap Trench, Fig. 12) and V374 (East Fayu, Fig. 14) where distinct current reversals occur. Points are essentially absent in the lower-left quadrant and tend to be in the lower-right quadrant for increasing positive velocities. This result indicates decreasing temperatures for growing throughflow and increasing temperatures for slackening or reversing flow. The 4670-m distribution for V371 (Yap Trench) and the 4589-m distribution for V372 (YMJ; Fig. 13) show no distinct temperature changes with velocity variations. A straight line indicating the correlation is therefore only given for the upper levels. If the 


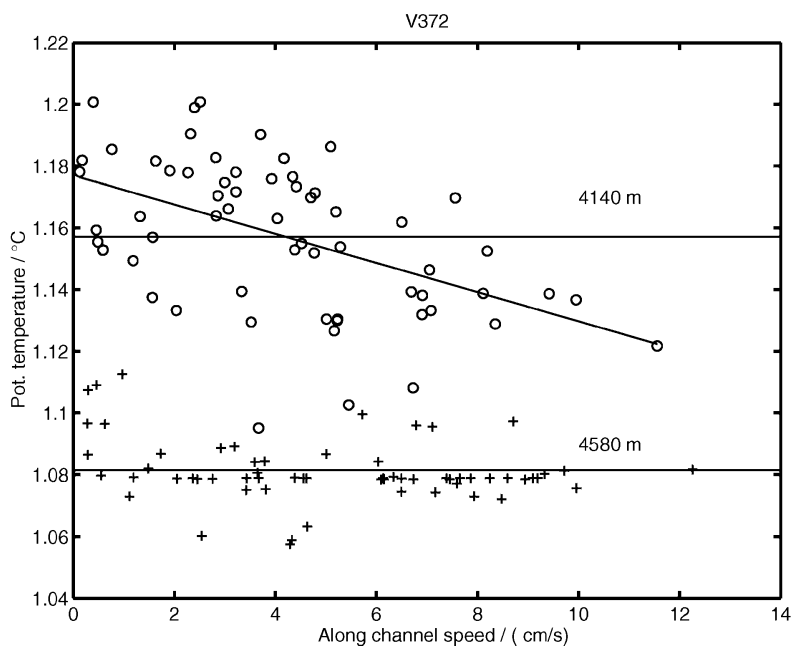

FIG. 13. As Fig. 13, but for mooring V372 (Yap-Mariana Junction).

vertical temperature gradient varied throughout the LCPW layer, changes should be seen at all these depths. The result obviously indicates that changes are mostly due to a variation in thickness of the LCPW layer and ensuing temperature changes near the upper boundary of this layer. Contrary to the data from V371 and V372, both datasets of V374 (East Fayu, Fig. 14) show a correlation. This result is not unexpected, because only the upper part of LCPW can go over the sill there.

\section{Conclusions}

By direct current measurements we confirm the westward propagation of Lower Circumpolar Water found earlier by indirect methods (Johnson and Toole 1993; Kawabe and Taira 1998). They suggested an inflow into

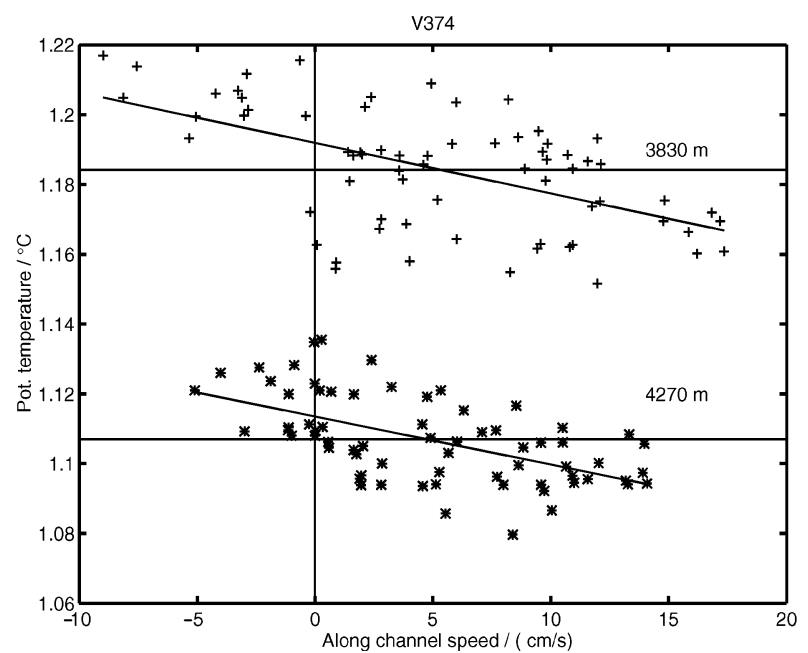

FIG. 14. As Fig. 13, but for mooring V374 (East Fayu).

the East Mariana Basin and a partial outflow to the West Mariana Basin. The present study also details the watermass distribution in the area.

A modified flow pattern in the southern East Mariana Basin is derived from the analysis (Fig. 15). At the latitude of $13^{\circ} \mathrm{N}$, the LCPW arrives from the north, apparently being blocked by bottom topography against an inflow directly from the east. A southward western boundary current is identified east of Guam at the slope of the Mariana Trench, with a branching of the transport into a westward and an eastward return transport. Overall, the LCPW not only continues to the west toward the West Mariana Basin (Johnson and Toole 1993), but also provides bottom water to the East Caroline Basin. Above the LCPW, we find an extension of the highsilica tongue of North Pacific Deep Water from the east

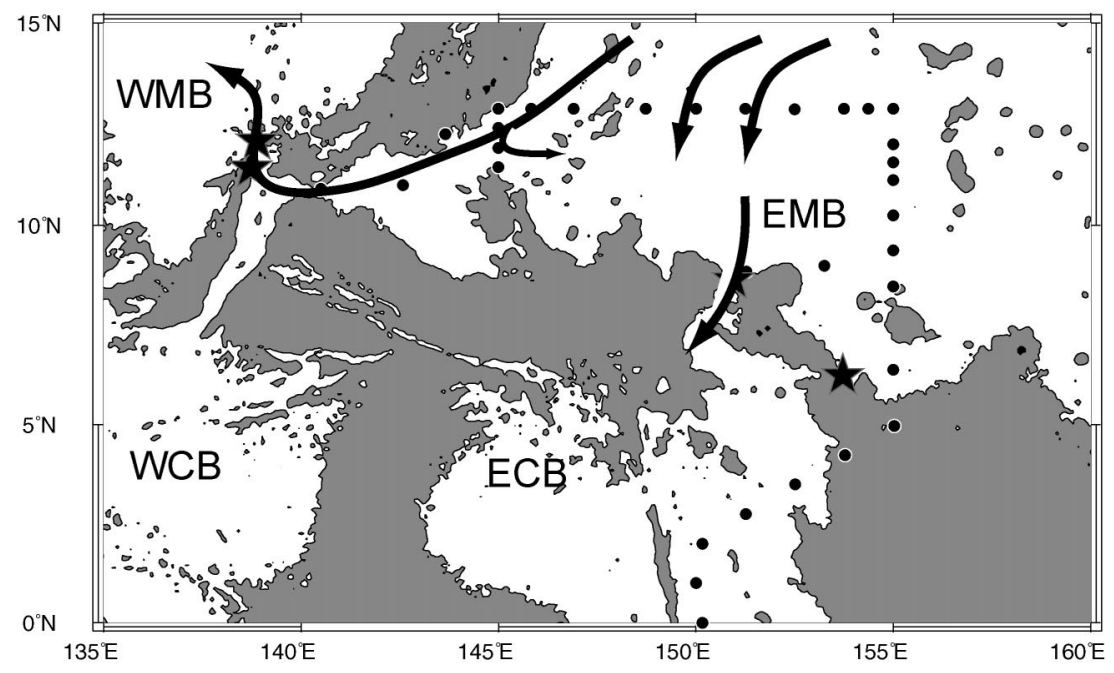

FIG. 15. Schematic LCPW flow pattern in the Mariana and Caroline Basins resulting from the present study. Dots give TROPAC stations, and stars indicate moorings. 
to the far western boundary of the East Mariana Basin, with the NPDW transport being mostly southward.

The channels that are critical for the exchange of the deepest water at the Yap Mariana Junction and at the Caroline Ridge (East Fayu), respectively, were identified with multibeam echosounder observations and moored current and temperature measurements. The throughflow is persistent between the East and West Mariana Basins, whereas some variability exists mostly on 3-4 month time scales at the Caroline Ridge. At the two locations, the throughflow changes are correlated with watermass property variations in a way that suggests layer thickness changes. Both geostrophic transport calculations and the independent (but rough) transport estimates from sill current measurements result in a total LCPW transport to the neighboring West Mariana and East Caroline Basins of about $1 \mathrm{~Sv}$, with the shallower part contributing to the East Caroline Basin. Although the transports are small, the Lower Circumpolar Water has a profound influence on the structure of deep water in the Mariana and Caroline Basins. Diapycnal mixing with a diffusion coefficient of order $10 \mathrm{~cm}^{2} \mathrm{~s}^{-1}$ is required to balance the LCPW inflow into and the resulting upwelling in the East Caroline Basin.

Acknowledgments. The authors are indebted to $\mathrm{R}$. Onken for his help in the planning of the TROPAC experiment, to the staff of the earlier Department of Marine Physics of the Institut für Meereskunde in Kiel, Germany, for many contributions to observations and data processing, and to the captains and crews of the research vessels Sonne and Hakuho Maru for most helpful advice and cooperation. We benefited from discussions with K. Taira and M. Kawabe and from their assistance in the German-Japanese mooring work. The first author performed part of the data analysis during a stay at the International Pacific Research Center (IPRC) at the School of Ocean and Earth Science and Technology (SOEST) of the University of Hawaii. The discussions with members of the IPRC and other colleagues at SOEST were much appreciated. The TROPAC project was funded by the German Ministry of Science and Technology (BMFT 03G0113A, 03F0176A, 03F0157A).

\section{REFERENCES}

Freeland, H., 2001: Observations of the flow of abyssal water through the Samoa Passage. J. Phys. Oceanogr., 31, 2273-2279.

Hogg, N., 2001: Quantification of the deep circulation. The tropical ocean circulation. Ocean Circulation and Climate, G. Siedler, J. Church, and J. Gould, Eds., Academic Press, 259-270.

—, P. Biscaye, W. Gardner, and W. J. Schmitz Jr., 1982: On the transport and modification of Antarctic Bottom Water in the Vema Channel. J. Mar. Res., 40 (Suppl.), 231-263.

- W. B. Owens, G. Siedler and W. Zenk, 1994: Circulation in the deep Brazil Basin. The South Atlantic, G. Wefer et al., Eds., Springer, 249-260.

Johnson, G. C., and J. M. Toole, 1993: Flow of deep and bottom waters in the Pacific at $10^{\circ}$ N. Deep-Sea Res., 40, 371-394.
— D. L. Rudnick, and B. A. Taft, 1994: Bottom water variability in the Samoa Passage. J. Mar. Res., 52, 177-196.

Jones, M. T., A. R. Tabor, and P. Weatherall, 1994: GEBCO Digital Atlas: CDROM and Supporting Volume. British Oceanographic Data Centre, Birkenhead, United Kingdom.

Kaneko, I., and T. Teramoto, 1985: Sea water exchange between the Shikoku-Philippine Basin and the western North Pacific Basin. Ocean Characteristics and their Changes, K. Kajiura, Ed., Koseisha Koseikaku, 54-77.

_-, Y. Takatsuki, H. Kamiya, and S. Kawae, 1998: Water property and current distributions along WHP-P9 section $\left(137^{\circ}-142^{\circ} \mathrm{E}\right)$ in the western North Pacific. J. Geophys. Res., 103 (C6), 12959 12984.

Kashino, Y., M. Aoyama, T. Kawano, N. Hendiarti, Syaefudin, Y. Anantasena, K. Muneyama, and H. Watanabe, 1996: The water masses between Mindanao and New Guinea. J. Geophys. Res., 101 (C5), 12 391-12 400.

Kawabe, M., 1993: Deep water properties and circulation in the western North Pacific. Deep Ocean Circulation and Chemical Aspects, T. Teramoto, Ed., Elsevier, 17-37.

_ _ and K. Taira, 1998: Water masses and properties at $165^{\circ} \mathrm{E}$ in the western Pacific. J. Geophys. Res., 103 (C6), 12 941-12 958.

_- S. Fujio, and D. Yanagimoto, 2003: Deep-water circulation at low latitudes in the western North Pacific. Deep-Sea Res., 50A, 631-656.

Klatt, O., and J. Holfort, 2000: Bottom water circulation in the western equatorial Pacific as inferred from carbon tetrachloride observations. Geophys. Res. Lett., 27, 545-548.

Levitus, S., and T. P. Boyer, 1994a: Temperature.Vol. 4, World Ocean Atlas 1994, NOAA Atlas NESDIS 4, 117 pp.

, R. Burgett, and T. P. Boyer, 1994b: Salinity. Vol. 3, World Ocean Atlas 1994, NOAA Atlas NESDIS 3, 99 pp.

Mantyla, A. W., 1975: On the potential temperature in the abyssal Pacific Ocean. J. Mar. Res., 33, 341-354.

— waters. Deep-Sea Res., 30, 805-833.

Reid, J. L., 1997: On the total geostrophic circulation of the Pacific Ocean: Flow patterns, tracers and transports. Progress in Oceanography, Vol. 39, Pergamon, 263-352.

_- and R. J. Lynn, 1971: On the influence of the NorwegianGreenland and Weddell Seas upon the bottom waters of the Indian and Pacific Oceans. Deep-Sea Res., 18, 1063-1088.

— Samoan Passage. J. Phys. Oceanogr., 4, 58-73.

Roemmich, D., S. Hautala, and D. Rudnick, 1996: Northward abyssal transport through the Samoan Passage and adjacent regions. $J$. Geophys. Res., 101, 14 039-14 056.

Rudnick, D. L., 1997: Direct velocity measurements in the Samoan Passage. J. Geophys. Res., 102 (C2), 3293-3302.

Schmitz, W. J., 1995: On the interbasin-scale thermohaline circulation. Rev. Geophys., 33, 151-173.

_- 1996a: On the World Ocean circulation: Volume I. Woods Hole Oceanographic Institution. Tech. Rep. WHOI-96-03, Woods Hole, MA, 140 pp.

_ 1996b: On the World Ocean circulation: Volume II. Woods Hole Oceanographic Institution. Tech. Rep. WHOI-96-08, Woods Hole, MA, 237 pp.

Siedler, G., and W. Zenk, 1997: Untersuchungen zu den tiefen Wassermassen und planktologische Beobachtungen im tropischen Westpazifik während der Sonne-Fahrt 113 (TROPAC) [Investigations of deep water masses and plankton observations in the tropical western Pacific during the Sonne cruise 113 (TROPAC)]. Ber. Inst. für Meereskunde Kiel, Nr. 288, 129 pp.

Smith, W. H. F., and D. T. Sandwell, 1997: Global sea floor topography from satellite altimetry and ship depth soundings. Science, 277, $1956-1962$.

Sokolov, S., and S. Rintoul, 2000: Circulation and water masses in the southwest Pacific: WOCE Section P11, Papua New Guinea to Tasmania. J. Mar. Res., 58, 223-268. 
Stommel, H., 1958: The abyssal circulation. Deep-Sea Res., 5, 8082.

_ , and A. B. Arons, 1960a: On the abyssal circulation of the World Ocean-I. Stationary planetary flow patterns on a sphere. DeepSea Res., 6, 140-154.

- and 1960b: On the abyssal circulation of the World Ocean-II. An idealised model of the circulation pattern and amplitude in oceanic basins. Deep-Sea Res., 6, 217-233.

Taft, B. T., S. P. Hayes, G. E. Friedrich, and L. A. Codispoti, 1991: Flow of abyssal waters in the Samoan Passage. Deep-Sea Res., 38 (Suppl. 1), S103-S128.

Talley, L., and T. Joyce, 1992: The double silica maximum in the North Pacific. J. Geophys. Res., 97, 5465-5480.

Uehara, K., and K. Taira, 1990: Deep hydrographic structure along $12^{\circ} \mathrm{N}$ and $13^{\circ} \mathrm{N}$ in the Philippine Sea. J. Oceanogr. Soc. Japan, 46, 167-176.

- , - and A. Masuda, 1993: Density field along $12^{\circ} \mathrm{N}$ and $13^{\circ} \mathrm{N}$ in the Philippine Sea. Deep Ocean Circulation and Chemical Aspects, T. Teramoto, Ed., Elsevier, 39-49.

Warren, B. A., 1973: Transpacific hydrographic sections at lats. $43^{\circ} \mathrm{S}$ and $28^{\circ} \mathrm{S}$ : The SCORPIO Expedition-II. Deep water. Deep-Sea Res., 20, 9-38.

Whitworth, T., III, B. Warren, W. D. Nowlin Jr., S. Rutz, R. Pillsbury, and M. Moore, 1999: On the deep western-boundary current in the Southwest Pacific Basin. Progress in Oceanography, Vol. 43, Pergamon, 1-54.

Wijffels, S. E., J. M. Toole, H. L. Bryden, R. A. Fine, W. J. Jenkins, and J. L. Bullister, 1996: The water masses and circulation at $10^{\circ} \mathrm{N}$ in the Pacific. Deep-Sea Res., 43, 501-544.

—, M. M. Hall, T. Joyce, D. J. Torres, P. Hacker, and E. Firing, 1998: Multiple deep gyres of the western North Pacific: A WOCE section along 149E. J. Geophys. Res., 103, 12 985-12 009.

Wüst, G., 1929: Schichtung und Tiefenzirkulation des Pazifischen Ozeans (Stratification and deep circulation of the Pacific Ocean). Veröff. Inst. für Meereskunde Univ. Berlin, Neue Folge A: geographisch-naturwissenschaftliche Reihe Heft 20, 1-64.

1930: Meridionale Schichtung und Tiefenzirkulation in den Westhälften der drei Ozeane (Meridional stratification and deep circulation in the west halves of the three oceans). J. Cons. Int. l'Expl. Mer, 5, 7-21.

1937: Bodentemperatur und Bodenstrom in der Pazifischen Tiefsee (Bottom temperature and bottom current in the Pacific deep sea). Veröff. Inst. für Meereskunde Univ. Berlin, Neue Folge A: geographisch-naturwissenschaftliche Reihe Heft 35, $1-$ 56

Wyrtki, K., 1961: The flow of water into the deep-sea basin of the western South Pacific Ocean. Aust. J. Mar. Freshwater Res., 12, $1-16$. 